\title{
NURSE MANAGER PERCEPTIONS OF PATIENT SAFETY STRATEGY IMPLEMENTATION ${ }^{1}$
}

\author{
Gislene Aparecida Xavier dos Reis², Liliana Yukie Hayakawa, Ana Claudia Yassuko Murassaki4, \\ Laura Misue Matsuda ${ }^{5}$ Carmen Silvia Gabriel ${ }^{6}$, Magda Lucia Felix de Oliveira ${ }^{7}$
}

${ }^{1}$ Article extracted from thesis - Segurança do paciente na perspectiva de enfermeiros gestores, presented to Programa de Pós-Graduação em Enfermagem, Universidade Estadual de Maringá (UEM), in 2016.

${ }^{2}$ M.Sc. in Nursing. Risk management coordinator. Hospital Santa Casa de Maringá. Maringá, Paraná, Brazil. E-mail: gislenereis@ gmail.com

${ }^{3}$ Doctoral student. Programa de Pós-Graduação em Enfermagem, UEM. Maringá, Paraná, Brazil. E-mail: lilihayakawa@hotmail.com

${ }^{4}$ M.Sc. in Nursing. UEM. Maringá, Paraná, Brazil. E-mail: anamurassaki@yahoo.com.br

${ }^{5}$ Ph.D. in Nursing. Professor, Programa de Pós-Graduação em Enfermagem, UEM. Maringá, Paraná, Brazil. E-mail: lmmatsuda@uem.br

${ }^{6}$ Ph.D. in Nursing. Professor, Programa de Pós-Graduação em Enfermagem Fundamental, Programa de Mestrado Profissional. Escola de Enfermagem de Ribeirão Preto, Universidade de São Paulo. Ribeirão Preto, São Paulo, Brazil. E-mail: cgabriel@eerp.usp.br

${ }^{7}$ Ph.D. in Nursing. Professor, Programa de Pós-Graduação em Enfermagem, UEM. Maringá, Paraná, Brazil. E-mail: micoleao@wnet. com.br

\begin{abstract}
Objective: to describe the patient safety strategy implantation process through the perspective of nurse managers.

Method: a qualitative descriptive-exploratory approach, performed with 72 nurse managers from four public university hospitals in Paraná. The data were collected through a recorded interview, guided by the question: "Tell me about your experience regarding the process of implantation of patient safety strategies?" and was submitted for content, thematic and modality analysis.

Results: categories resulting from the analysis: Understanding the trajectory of patient safety strategy implantation; Multiple phases of patient safety strategy implantation; and Ambiguous feelings related to patient safety strategy implantation.

Conclusion: in the investigated institutions, despite the process of patient safety strategy implantation being perceived in a contradictory way by the participants, they expressed feelings of satisfaction.

DESCRIPTORS: Nursing. Patient safety. Security management. Perception. Risk management.

\section{IMPLANTAÇÃO DAS ESTRATÉGIAS DE SEGURANÇA DO PACIENTE: PERCEPÇÕES DE ENFERMEIROS GESTORES}

\section{RESUMO}

Objetivo: descrever, na percepção de enfermeiros gestores, o processo de implantação das estratégias de segurança do paciente.

Método: pesquisa descritivo-exploratória, de abordagem qualitativa, realizada com 72 enfermeiros gestores de quatro hospitais universitários públicos paranaenses. Os dados foram coletados por meio de entrevista gravada, norteada pela questão: Fale-me do processo de implantação das estratégias de segurança do paciente deste hospital, vivenciado pelo senhor/senhora/você e submetidos à análise de conteúdo, modalidade temática.

Resultados: da análise das entrevistas, emergiram as categorias: Compreendendo a trajetória de implantação das estratégias de segurança do paciente; Múltiplas fases de implantação das estratégias de segurança do paciente; e Sentimentos ambíguos relacionados à implantação das estratégias de segurança do paciente.

Conclusão: nas instituições investigadas, o processo de implantação das estratégias de segurança do paciente é percebido de forma contraditória pelos participantes, mas, apesar disso, emitiram sentimentos de satisfação.

DESCRITORES: Enfermagem. Segurança do paciente. Gestão da segurança. Percepção. Gestão de riscos. 


\section{IMPLANTACION DE LAS ESTRATEGIAS DE SEGURIDAD DEL PACIENTE: PERCEPCIONES DE ENFERMEROS GESTORES}

\section{RESUMEN}

Objetivo: describir en la percepción de enfermeros gestores, el proceso de implantación de las estrategias de seguridad del paciente.

Método: investigación descriptiva-exploratoria, de abordaje cualitativa, realizada con 72 enfermeros gestores de cuatro hospitales universitarios públicos paranaenses. Los datos fueron recolectados por medio de entrevista grabada, norteada por la pregunta: Hábleme del proceso de implantación de las estrategias de seguridad del paciente de este hospital, vivenciado por usted y sometidos a análisis de contenido, en la modalidad temática.

Resultados: del análisis de entrevistas, surgieron las categorías: Comprendiendo la trayectoria de implantación de las estrategias de seguridad del paciente; múltiples fases de implantación de las estrategias de seguridad del paciente y; sentimientos ambiguos relacionados a la implantación de estrategias de seguridad del paciente.

Conclusión: en las instituciones investigadas, el proceso de implantación de las estrategias de seguridad del paciente es percibido de forma contradictoria por los participantes, más a pesar de esto, emitieron sentimientos de satisfacción.

DESCRIPTORES: Enfermería. Seguridad del paciente. Gestión de la seguridad. Percepción. Gestión del riesgos.

\section{INTRODUCTION}

Based on the hippocratic principle, "first do no harm", the issue of patient safety has been recognized worldwide and remainsa major challenge for health organizations. This is because, in the area of health, risks are inherent to the work process and there is a high incidence of harm to the patient, which can lead to prolonged hospitalization, permanent injuries and even death. ${ }^{1}$

Harm resulting from health care ispresent in institutions generally caused by work overload, often coupled with inadequate staffing and the lack of trainedworkers. ${ }^{2}$ In addition, the literature points to other factors, such as ineffective communication, difficulty in the interpersonal relationship between health professionals, and lack of leadership knowledge regarding the weaknesses and potentialities of the team..$^{3-5}$

In view of the above, in 2002 the World Health Organization (WHO) reacted to the need to reduce risks and preventable harm to patients as a result of health care, and recommended that all countries develop strategies to promote safe care. ${ }^{6}$

In order to meet the aforementioned proposal, in Brazil, the Ministry of Health (MS) instituted the National Patient Safety Program (PNSP), with the objective of improving the quality of health care through the implantation of goals aimed at patient safety, including: correctly identifying the patient; improving communication among health professionals; improving prescription safety, use and administration of medicines; confirming surgery site, procedure and correct patients; sanitizing hands to avoid infection; and reduce the risk of falls and pressure sores. ${ }^{7}$

These goals constitute an extremely important step in obtaining safe care, but in order to achieve them, changes in the organizational culture of the hospital and focusing on learning from mistakesarenecessaryaspects. ${ }^{8}$ This change, in turn, involves complex processes in the search to reorganize care, because communication is necessary to be based on mutual trust between employees and for top management to recognize that poorly delineated processes which lead to the mistakes and errors. ${ }^{9}$

It should be mentioned that, although national and international organizations are encouraged to promote safe care, there are still structural factors that make it difficult to guarantee patient safety. Among the causes that favor the occurrence of unintentional errors during patient care include, inadequate staffing, work overload, stress, poor training and organizational culture aimed at resistance to change. ${ }^{10}$ In such environments, as leader and manager of the care process, the nurse has a fundamental role to promote safe care throughout the time the patient stays in the health institution.

Considering that in the health care process the risk of harming the patient is greater when the institutional processes are not planned or are planned inadequately, this study is justified because the unveiling and the dissemination of information that contributes to the prevention of harm to the patient is of paramount importance, especially when it refers to the implantation process of strategies focused on safety.

Based on the above, it is questioned: what is the process of patient safety strategy implantation in public university hospitals in Paraná? To answer this question, the present study aims to describe, the process of implantation patient safety strategies in hospitals through the perspective of nurse managers. 


\section{METHOD}

A descriptive-exploratory study, with a qualitative approach, carried out from January to March 2015, in four public university hospitals, located in the State of Paraná.

Seventy-two nurses who were initially identified with assistance from the human resources sector of each hospital, who provided the nurse service organization chart with the name, position, date of admission to the institution, telephone contact and/or e-mail address. From this information, all the nurses who performed indirect activities to the patient, here called nurse managers, who had been in the institution for more than a year and who had been in the current position for at least six months, were selected.

After the selection of the nurse managers, a telephone and/or e-mail and/or personal contact with them was carried out so that the researcher could provide information regarding the purpose of the study, data collection technique and ethical implications. Through informal acceptance, the interview was scheduled according to the availability of each participant and held in the workplace of each nurse manager, in a quiet reserved place. It should be noted that prior to the interviews, two copies of the Free and Informed Consent Form was made available for the participant to read and sign.

The data collection was done through a form to acquire information regarding the socio-demographic and labor characterization of the participants and the interview was recorded using audio, based on the guiding question: Tell me about your experience regarding the process of patient safety strategy implantation of this hospital.

After the data collection, all material was transcribed in its entirety, and then the data were processed and analyzed using the content analysis technique in thematic modality. This analysis consists of three phases: pre-analysis, material exploration and processing of data obtained and interpretation. ${ }^{11}$

For the previous analysis of the data, a table with two columns, one for the insertion of the transcribed material and the other for future annotations was used. Then, the research question and the objective was stated again as to allow for the organization of the main ideas that guide the study.

In the pre-analysis, a superficial/floating reading of each interview was carried out, highlighting the researcher's points of interest, followed by thorough and exhaustive readings of all the material, with coding of the messages existing in the texts. ${ }^{11}$
As well as performing codification of the messages , the material was grouped into categories. After the categorization was finished, the inference was obtained from the context of the language, the interviewee's conditions and their meanings. ${ }^{11}$

In order to present the results, the excerpts/ verbatins were edited in order to correct possible grammatical errors without, however, changing the content. In addition, in some parts, some terms / words were added between brackets. To preserve the identification of participants, the excerpts were coded by the letter " $\mathrm{E}$ " for interview, and " $\mathrm{H}$ ", to name the hospital where the interview took place. In addition, an arabic number was used to indicate the sequence of the interviews.

This study is part of a larger project titled "Management in Health / Nursing: quality and patient safety in university hospitals", it adhered to all Brazilian ethical precepts and is registered in the Brazilian Platform with CAAE number 32206414.6.1001.0104.

\section{RESULTS}

Out of the 72 professionals interviewed, $26.4 \%$ worked in $\mathrm{H} 1 ; 39 \%$ in $\mathrm{H} 2 ; 15.2 \%$ in $\mathrm{H} 3$; and $19.4 \%$ in $\mathrm{H} 4$. There was a higher female prevalence in all hospitals $(\mathrm{H} 1=94.7 \%, \mathrm{H} 2=92.9 \%, \mathrm{H} 3=82 \%, \mathrm{H} 4=86 \%)$. Regarding the age group, $47.3 \%$ of the nurses who managed in $\mathrm{H} 1$ were between 50 and 59 years old; $42.8 \%$ in $\mathrm{H} 2$, and $63.7 \%$ inH3 were respectively between 40 and 49 years of age; And $71.4 \%$ of $\mathrm{H} 4$ participants were between 30 and 39 years of age.

Three thematic units emerged from data analysis: Understanding the trajectory of patient safety strategy implantation; Multiple phases of patient safety strategy implantation and Ambiguous feelings related to patient safety strategy implantation.

\section{Understanding the trajectory of patient safety strategy implantation}

Although the term safety culture is relatively new in the area of health, it was observed through the analysis of the nurse manager reports, before patient safety strategy implantation existed, there were efforts to promote safety culture in the hospitals investigated: before the [safety] strategies, a group in 2012 initiated proposals to promote safety culture (H1E1); we started the discussion of safety strategies in 2009, with the development of the [safety] culture, which until then was not explored, was not spoken of in the hospital [...] (H2E1). 
Participants also pointed out that during the patient safety strategy implantation, the Patient Safety Center (NSP) was formed at the institution to support the safety actions: [...] the Risk Center [...] with several people from the hospital, each one being responsible for a protocol ... (H3E3); [...] there was a Patient Safety Commission prior to RDC No.36. After that, all these Committees formed a Patient Safety Center (H4E6).

The nurses' managers reported having carried out training activities for their employees, through lectures and the delivery of pamphlets to disseminate knowledge about patient safety: since 2012, we have had an approximation to international goals [...] (H2E8); [...] a lecture was given and a pamphlet was delivered and we worked with the team in the units (H1E11); We conducted some training [on patient safety] because it is a new subject in the institution (H4E6).

By listening to the others, the nurse manager can help to improve the quality of the services and, consequently, minimize the risk of damages and harm, as shown in the following extract: you have to listen to the people involved in the process [...] we have to raise issues and this can only happen if we listen to people who provide direct care ... because when [the idea] is theirs it can be improved [...], they want it to work (H2E3).

In the testimony regarding the trajectory of the patient safety strategy implantation, it was possible to identify statements that show resistance of the professionals to adhere to the measures proposed for the practice of safe care: we plan, but only some people have adhered to the changes. The others are against what was proposed and only cause obstacles... you plan something, but one person adheres to the idea and everyone else tries to destroy it. You fight, and fight but $v$ you cannot get anywhere (H3E8); when we started identifying the patient using the bracelets, I observed a resistance from, the colleague in identifying the patient, resistance to printing the bracelets, resistance of the collaborator of the concierge. In short, I noticed several resistances (H4E2); It is difficult to implant [safety] strategies because the staff is resistant to change (H4E3).

\section{Multiple phases of patient safety strategy implementation}

Although the regulations related to the promotion of patient safety strategies were instituted by the Ministry of Health in 2013, the investigated hospitals are in distinct stages of implantation. One of them, through the hospital accreditation process, is ahead of the others and this was verified in the following discourse: we have already implanted patient safety strategies for accreditation, so they are already being re-evaluated and re-adapted (H1E16).

In hospital institutions that did not experience the hospital accreditation process, the nurse managers pointed out that patient safety strategy implementation was under development: the implantation will take place in 2015, together with the [Patient] Safety Center (H2E4); As of this year [2015] patient safety strategies will be the main focus [...] they will be implemented and placed in strategic planning (H2E25); We plan to deploy all patient safety strategies through the Patient Safety Center (H2E11) by 2015.

According to the reports, at the time of this study, the hospital was being organized for the first initiatives regarding the implementation of safe care. And this can also be perceived in the discourses: [...] effectively implemented no, they are being constructed (H3E4); we already have [patient safety] protocols, but we haven't implemented them yet (H3E9); what I have noticed is that they are not implemented because we are holding meetings to discuss strategies (H3E10).

There were also participants who did not remember the stage that the hospital was in, in relation to the patient safety strategies implementation: I am not aware of these strategies. In relation to the patients, I can see that a lot of work is needed herein the hospital, for the patient to be safe (H4E1); Look, I actually don't know that much about it [about patient safety strategies], I know it's a program, it has to be deployed, and it brings benefits to the patient (H4E2); if they were implemented [the patient's safety goals] effectively, I can't remember any (H4E10).

\section{Ambiguous feelings related to the implementation of patient safety strategies}

The process of organizational change generates expectations for employees, whether positive or negative, especially for those who lead the movement. This conception can be seen in the following excerpts regarding the implementation of the strategies: [...] although I realize that we are far behind in some issues, I am very happy to participate in all these strategies (H1E15); I am satisfied in seeing this process happening in the hospital and thinking that, more and more, we will provide safety for patients and professionals (H3E11).

Despite the satisfaction, there were nurses who expressed negative perceptions regarding the professionals' resistance to adhering to patient safety strategies: I see some professionals working, searching and researching in a wonderful, revolutionary way [knowledge to promote safe care], but this ends 
up being diluted and despised by other workers. When I see this, I feel pain in my heart, literally! (H4E2); I realize that it is very important to implement [patient safety] strategies, but not all [strategies] are accepted and implemented (H2E16).

Different perceptions were also observed regarding the implementation phase: [...] I was pleased to have started the implementation process [of patient safety strategies] before the Ministry of Health regulation and now I am frustrated because, we are behind other hospitals (H2E11); I realize that it is extremely stressful work, but at the same time very rewarding because you can see the positive results [from the implementation of patient safety strategies] (H1E15).

\section{DISCUSSION}

The goal of implementing patient safety strategies is to reduce unnecessary health care risks to a minimum. ${ }^{12}$ In order for hospital organizations to be successful during the process of implementing such strategies, it is essential to strengthen positive safety culture. ${ }^{6}$

According to the excerpts, hospitals had already turned their attention to the practice of safe care, following international patient safety goals. This is worth highlighting, because the confirmation that Brazilian public university hospitals started discussions about patient safety prior to Brazilian regulations shows that managers are concerned about providing quality patient care. With regard to the role of the leader in the process of initiating and implementing the safety culture, it is proposed that it should lead the people through effective communication, professional development promotion, through training, encouragement of safe practices and achievement of feedback from the analysis of events. ${ }^{13}$

Thus, inthis context the role of the nurse stands out, the nurse leadsthe largest team that provides health careto patients, has managerial skills and is the professional responsible for most decisions related to the quality of health care.${ }^{14}$ In addition to being the care manager of the care process, thenursehas the basic role of promoting safe care throughout the time the patient stays in the health care facility.

The reports about the formation of the NSP during the process of patient safety strategies implementation indicate that nurses understand the importance of considering the national guidelines so that patient safety strategies are carried out in health institutions. This is because, according to the Resolution of the Collegiate Board of Directors (RDC) n. 36, of 2013, the MS establishes the implantation of NSP in the hospital services, being able to undergo penal sanctions through noncompliance with said law. ${ }^{15}$

Also with reference to the NSP, the participants report that the center is composed of several professionals and this is consistent with what is stated in RDC n. 36, which recommends the participation of a multi-professional team trained in concepts related to quality, patient safety and risk management tools, as well as being professionals with a leadership profile. ${ }^{15}$

The speeches related to employee training indicate that the participants, in order to implement patient safety strategies, carried out actions aimed at disseminating knowledge regarding the subject. This strategy is recommended because it tends to promote significant changes in the safety culture of organizations, contributing to the development of the skills and competences necessary for the safe care of the patient. ${ }^{16-17}$

Listening to the patients is an important item in the process of improving the quality of care, since the implementation of patient safety strategies involves, mainly, the professionals who are involved with the direct care to the patient. Thus, in order for the nurse to identify assistance situations that need improvement, it is necessary to use educational actions guided by the daily life experience and to have discussions and moments of reflection with the staff about the care being provided..$^{18}$

Thus, it is suggested that providing time for the team to listen and to expose their opinion causes them to feel part of the process and, consequently, to dedicate themselves more, so that the strategies achieve the expected result. Therefore, valuing the knowledge and experiences of individuals is a factor of extreme importance for ensuring the safe care, because any change requires participation at all levels of the organization. ${ }^{19}$

The excerpts mentioned the resistance of professionals to adhere to the measures proposed for the practice of safe care, it can be seen that resistance to change may be related to the organizational culture existing in public institutions. The feeling of stability of professionals of public institutions, in some situations, can affect the accomplishment of the activities, because the worker can execute them in the way that suits him or, simply, do not execute them at all, turning the process of change into something complex and costly. ${ }^{20}$

Resistance to change can be caused by uncertainties in individuals, which affects them psychologically and causes fear and, consequently, 
resistance. ${ }^{21}$ Therefore it is understood that when the subject is about changes, resistance is one of the greatest challenges for managers, because, usually, everything that is unknown, that escapes normality, causes a natural tendency to resistance. ${ }^{22}$

In order to minimize this situation, it is necessary that all levels of the organization participate in the process of change. ${ }^{19}$ Therefore, professionals at the most basic level can: understand the need for change, participate in decisions and feel involved; leaders can direct the process and motivate the professionals; and senior management can make human and material resources available..$^{23-25}$

It is observed that the trajectory experienced by nurse managers in the process of implementation of patient safety strategies was permeated by the promotion of safety culture, NSP training, involvement and listening to employees and also by the professionals' resistance in improving assistance to the patient.

According to the H1E16 excerpt, implementing patient safety strategies in an organization that has experienced the accreditation process may have ensured further advances in the area of safe care compared to other institutions. In this context, it should be mentioned that the first Accreditation Level, based on the National Accreditation Organization model, mainly focuses on adequacies related to patient structure and safety, ${ }^{26}$ emphasizing goals similar to those stipulated by the PNSP.

The Hospital Accreditation process acts as an important change promoter in the institution, with emphasis on greater engagement and effective communication among employees, a positive organizational culture, patient-oriented care, and management process focused on safe practices. ${ }^{27-30}$

It is observed that, despite the MS having instituted the PNSP, in order to minimize the damages resulting from health care, two hospital organizations are still in the implementation phase of patient safety strategies. This may be due to hospitals' difficulties in developing a positive safety culture. Non-incorporation of this culture may negatively interfere with actions in favor of safe care, which may lead to a higher incidence of adverse events, ${ }^{9}$ when compared to the services they value for the patient's safety strategies. ${ }^{31}$

There were also participants who did not remember the stage of implementation the hospital was in. Knowledge about safe care is necessary for the manager to know and understand the failures in care and assistance and thus adopt effective preventive measures against the errors. ${ }^{5}$ In addition, the lack of leadership training regarding safe strategies is one of the main barriers to its effectiveness. ${ }^{32}$ Therefore, it is necessary for the nurse manager to identify the need to improve their knowledge regarding safe care so that patients, professionals and the institution can be more assured. ${ }^{33}$

The process of implementing patient safety strategies should involve all professionals, directly or indirectly involved in health care. In this context, the participation of nurses is fundamental in the construction and implementation of safe care, since this professional is equipped with technical and scientific knowledge, leads the largest contingent of workers of the institution and is responsible for providing care to the patient during the 24 hours of the day. ${ }^{14.30}$

Therefore, three of the four investigated institutions are still in the initial phase, although Brazilian legislation states that all health facilities need to implement patient safety measures.

Every movement for change causes positive or negative perceptions, especially in those who lead the process. ${ }^{19}$ The discourses indicate that H1E15 and H3E11 are pleased to participate in the process of implementing patient safety strategies. The participation of professionals in actions that modify the work process in the institution causes positive perceptions for the opportunity of new experiences and to enhance knowledge. ${ }^{19}$ This fact is also directly related to the quality of care and, consequently, the development of safe practices. ${ }^{34-35}$

The satisfaction in providing patient and professional safety can be seen in the H3E11 testimony, which converges with the affirmation that the professional when adhering to the safe practices will see benefits because, once the errors are diagnosed and the failures in the processes are corrected, the employee will have better working conditions and satisfaction with the profession. ${ }^{36}$ In addition, it means that the patient will have the benefit of receiving safe and quality assistance and the organization, in turn, will have credibility and reduction in costs.

In spite of the above satisfaction, there were nurses who expressed negative perceptions due to the professionals' resistance to adhere to the patient's safety strategies. The perception of sadness is strongly evidenced in the discourse of H4E2, when he said that he feels "pain in his heart" by the lack of adherence to the strategies. This grief can be observed by the non-verbal communication of the interviewee, because at that moment there was a decrease in his tone of voice and the gaze became distant towards the door of the room. 
During the change process it is common for individuals to show resistance because of the fear of experiencing new things and due to the habit of carrying out the same activities for a long period of time. ${ }^{19}$ Through this, the manager should provide activities that encourage employees to understand the benefits of change and thus obtain adherence to the proposed actions. ${ }^{25}$

The extract from H2E11 discourse indicates that the implantation of the strategies before the Brazilian norm produced satisfaction in the work, but, because of the delay, he feels disappointed. In such situations, the leader has an influential role in the success of implementing patient safety strategies and, when detecting feelings of frustration in the team, needs to act in order to contain the emotions, so as not to influence patient care and, also in the interpersonal relationship between professionals. ${ }^{36}$

Based on this report, it can be inferred that the interviewee feels worried about the strategy implementation process being delayed in relation to other hospitals. Thus, leading the institution towards the implementation of safe practices can cause great concern to the managers, because the resulting success or failure is often the result of the professional wholeadsit. ${ }^{19}$

In general, nurses' perceptions regarding the implementation of strategies were ambiguous, as it was noted that some reported satisfaction for improving the quality of care. Others said they were disappointed by the delay in implementing the strategies and also by the resistance of other workers to join the process.

Due to the interviews being conducted with only nurse managers, this fact can be considered a limitation to the study. However, this study benefits managers, especially nurse managers, who seek to comply with MS standards regarding the implementation of patient safety strategies. This is because the information obtained can assist them in planning and making assertive decisions on the subject.

\section{CONCLUSION}

In the perception of nurses, several actions are still necessary for the effective implementation of patient safety strategies in the institutions, such as safety culture development, NSP training and staff training. In this context, the team has an important commitment to perform safety practices and for this to work effectively the nurse manager must be the foundation of this process.

In addition, these professionals also mentioned that the delay in the implementation of the goals of safe care has caused some feelings of disappointment in some, but for others the possibility to participate in the process of implementation of the safety goals and with that, to offer safe assistance to the patient and this brings forth feelings of satisfaction in the professional.

As an alternative for new investigations, we suggest quantitative approach studies with nurses and also with the participants that make up the multidisciplinary team from different locations, that measure the impact of the implantation of the safe strategies, either for the patient/user or for the workers.

\section{REFERENCES}

1. World Health Organization (WHO). Patient Safety. [Internet]. 2013 [cited 2015 Out23]. Avaliablefromhttp://www.who.int/topics/patient_ safety/en/

2. Umpierrez AF, Fort ZF, Tomas VC. Eventos adversos na saúde e os cuidados de enfermagem: a segurança dos pacientes desde a experiência do profissional. Texto Contexto Enferm [Internet].2015 [cited 2015 Nov 11]; 68(1):144-54. Available from http://www. scielo.br/scielo.php?script $=$ sci_arttext\&pid $=$ S003471672015000100144\&lng=en

3. Aiken LH, Sermeus W, Heede KV, Sloane DM, Busse R, McKee M, et al. Patient safety, satisfaction, and quality of hospital care: cross sectional surveys of nurses and patients in 12 countries in Europe and the United States. BMJ. 2012 [cited 2015 Nov 11];344:1717. Availablefromhttp://www.bmj.com/content/344/ bmj.e1717

4. Bohomol E, Tartali JA. Eventos adversos em pacientes cirúrgicos: conhecimento dos profissionais de enfermagem. Acta Paul Enferm[Internet]. 2013 [cited 2015 Nov 11]; 26(4):376-81. Available from http:/ / www.scielo.br/scielo.php? script $=$ sci $_{-}$ arttext\&pid=S0103-21002013000400012\&lng=en

5. Parand A, Dopson S, Renz A, Vincent C. The role of hospital managers in quality and patient safety: a systematic review. BMJ Open [Internet]. 2014[cited 2015 Nov 11];4:e005055. Availablefromhttp:// bmjopen.bmj.com/content/4/9/e005055

6. World Health Organization (WHO). The Conceptual Framework for the International Classification for Patient Safety. Final Technical Reportand Technical Annexes [Internet]. 2009 [cited 2015 Out 25]. Available from http://goo.gl/dM6IN.

7. Ministério da Saúde (BR). Agência Nacional de Vigilância Sanitária, Resolução Diretoria Colegiada $n^{\circ} 36$, de 25 de julho de 2013: Institui ações para a segurança do paciente em serviços de saúde e dá outras providências. Brasília (DF): MS; 2013.

8. Françolin L, Gabriel CS, Bernardes A, Silva AEBC, Brito MFP, Machado JP. Patient safety management from the 
perspective of nurses. Rev. esc. enferm. USP [Internet]. 2015 Apr [cited 2016 Jan 11]; 49(2):277-83. Available from http:/ / www.scielo.br/scielo.php?script=sci_ arttext\&pid=S0080-62342015000200277\&lng=en

9. Marinho MM, Radünz V, Barbosa SFF. Assessment of safety culture by surgical unit nursing teams. Texto Contexto Enferm [Internet]. 2014 Sep [cited 2016 Jan 11]; 23(3):581-90. Available from http://www. scielo.br/scielo.php?script=sci_arttext\&pid=S010407072014000300581\&lng=en.

10. Reis CT, Martins M, Laguardia J. A segurança do paciente como dimensão da qualidade do cuidado de saúde - um olhar sobre a literatura. Ciênc Saúde coletiva [Internet]. 2013 Jul [cited 2016 Jan 11]; 18(7):2029-36. Available from http://www. scielo.br/scielo.php?script=sci_arttext\&pid=S141381232013000700018\&lng=en

11. Bardin L. Análise de conteúdo. Lisboa (pt): Edições 70, 2011.

12. World Health Organization (WHO). World Alliance for Patient Safety [Internet]. 2011 [cited 2015 Out23]. Avaliable from: http://www.who.int/patientsafety/ worldalliance/en/

13. Onã PMP. Are there differences in patient safety between different countries using the HSOPSC? [Master of Public Health]. Copenhagen. (DK): Copenhagen University; 2012.

14. Siman AG, Brito MJM, Carrasco MEL. Participação do enfermeiro gerente no processo de acreditação hospitalar. Rev Gaúcha Enferm [Internet]. 2014 Jun [cited 2016 Jan 11]; 35(2):93-9. Available from http:/ / www.scielo.br/scielo.php?script=sci_ arttext\&pid=S1983-14472014000200093\&lng=en

15. Ministério da Saúde (BR). Portaria n. 529, de $1^{\circ}$ de abril de 2013. Institui o Programa Nacional de Segurança do Paciente. Brasília (DF): MS; 2013.

16. Rigon AG, Neves ET. Educação em saúde e a atuação de enfermagem no contexto de unidades de internação hospitalar: o que tem sido ou há para ser dito? Texto Contexto Enferm [Internet]. 2011 Dec [cited 2016 Jan 11]; 20(4):812-7. Available from http://www. scielo.br/scielo.php?script=sci_arttext\&pid=S010407072011000400022\&lng=en

17. Miake-Lye IM, Hempel S, Ganz DA, Shekelle PG. Inpatient fall prevention programs as a patient safety strategy: a systematic review. Ann Intern Med [Internet]. 2013 Mar [cited 2016Jan 15]; 158(2):390-96. Available from https://www.ncbi.nlm.nih.gov/ pubmed/23460095

18. Thomas L, Galla C. Building a culture of safety through team training and engagement. BMJ Qual Saf [Internet]. 2012 Dec [cited 2016 Jan 15]; 22(5):42534. Available from: http://qualitysafety.bmj.com/ content/early/2012/12/03/bmjqs-2012-001011

19. Carvalho PS. Cultura e mudança organizacional: compreendendo o indivíduo na organização. Psicologia; 2015. Jul [cited 2016 Jan 15]; 22(5):425-34.
Available from: http:/ / www.psicologia.pt/artigos/ textos/A0893.pdf

20. Guimarães AT, VaghettiHH, Lunardi FilhoWD, Gomes GC. Gerenciamento do pessoal de enfermagem com estabilidade no emprego: percepção de enfermeiros. Rev Bras Enferm [Internet]. 2011 Out [cited 2016 Jan 11]; 64(5):905-11. Available from http://www. scielo.br/scielo.php?script=sci_arttext $\&$ pid=S003471672011000500016\&lng=en

21. Freires DAN, Gouveia VV, Bortolotti SLV, Ribas FTT. Resistência à mudança organizacional: perspectiva valorativa e organizacional. Psico [Internet]. 2014 Out-Dez [cited 2016 Jan 11]; 45(4):51323. Availablefromhttp:// revistaseletronicas. pucrs.br/ojs/index.php/revistapsico/article/ view/16220/12478

22. Haslam S, Pennington R. Reducing resistance to change and conflict: A key to successful leadership. Resource International [Internet]. 2010 [cited 2016 Jan 11]; 1:3-11. Available from http:/ / ww.w.resource-i. com/PDFs/Leadership_series1.pdf

23. Robbins SP, Judge TA, Sobral F. Comportamento organizacional - teoria e prática no contexto brasileiro. $14^{\mathrm{a}}$ ed. São Paulo: Pearson Prentice Hall; 2010.

24. Kim TG, Hornung S, Rousseau DM. Change supportive employee behavior: antecedents and the moderating role of time. J Manag [Internet]. 2010 [cited 2016 Jan 11]; 37:1664-93. Available from http://jom.sagepub. com/content/early/2010/04/08/0149206310364243

25. Nery VF, Neiva ER. Variáveis de contexto e respostas à mudança organizacional: testando o papel mediador das atitudes. Psic:Teor e Pesq [Internet]. 2015 [cited 2016 Jan 11]; 31(2):259-68. Availablefrom https:// revistaptp.unb.br/index.php/ptp/article/view/1968

26. Organização Nacional de Acreditação (ONA). Manual das organizações prestadoras de serviços de saúde. Brasília (DF): ONA; 2014.

27. Alkhenizan A, Shaw C. Impact of Accreditation on the Quality of Healthcare Services: a Systematic Review of the Literature. Ann Saudi Med [Internet]. 2011 Jul-Aug [cited 2016 Jan 11];31(4):407-16. Available from https:/ / www.ncbi.nlm.nih.gov/pmc/articles/PMC3156520

28. Ng GKB, Leung GKK, Johnston JM, Cowling BJ. Factors affecting implementation of accreditation programmes and the impact of the accreditation processon quality improvement in hospitals: a SWOT analysis. Hong Kong Med J [Internet]. 2013 Out [cited 2016 Jan 11]; 19(5):434-46. Available from https:/ / www.ncbi.nlm.nih.gov/pubmed/24088588.

29. Mendes GHS, Mirandola TBS. Acreditação hospitalar como estratégia de melhoria: impactos em seis hospitais acreditados. Gest Prod [Internet]. 2015 [cited 2016 Jan 11]: 22(3):636-48. Available from http:/ / www.scielo. br/scielo.php?script=sci_arttext\&pid=S0104-530X20 15000300636\&lng=en\&nrm=iso

30. Oliveira JLC, Matsuda LM. Acreditação: possibilidade para o avanço na gestão da qualidade em saúde e em 
enfermagem. Cienc Cuid Saude [Internet] 2015[cited 2016 Jan 11]: 14(2):993-4. Available from http:// periodicos.uem.br/ojs/index.php/CiencCuidSaude/ article/view/28142

31. Roque KE, Melo ECP. Avaliação dos eventos adversos a medicamentos no contexto Hospitalar. Esc Anna Nery [Internet]. 2012 Mar [cited 2016 Jan 11]; 16(1):121-7. Available from http://www. scielo.br/scielo.php?script=sci_arttext\&pid=S141481452012000100016\&lng=en

32. Ques AAM, Montoro CH, González MG. Fortalezas e ameaças em torno da segurança do paciente segundo a opinião dos profissionais de enfermagem. Rev LatinoAm Enfermagem [Internet]. 2010 Jun [cited2016 Jan 11]; 18(3):339-45. Available from http://www. scielo.br/scielo.php?script=sci_arttext\&pid=S0104$11692010000300007 \& \operatorname{lng}=$ en

33. Inoue KC, Matsuda LM. Segurança do paciente: abordando um antigo problema. CiencCuidSaude[Internet] 2013 [cited 2016 Jan 11]; 12(2):208-9.Availablefrom http://eduem.uem.br/
ojs/index.php/CiencCuidSaude/article/view/23880

34. Rigobello MCG, Carvalho REFL, Cassiani SHB, Galon T, Capucho HC, Deus NN. Clima de segurança do paciente: percepção dos profissionais de enfermagem. Acta Paul. Enferm [Internet]. 2012 [cited 2016 Jan 11]; 25(5):728-35. Available from http://www. scielo.br/scielo.php?script=sci_arttext\&pid=S010321002012000500013\&lng=en

35. Bassuni EM, Bayoumi MM. Improvement critical care patient safety: using nursing staff development strategies, at Saudi Arabia. Glob J Health Sci[Internet].2015Jan [cited 2016 Jan 11];7(2). Available fromhttps://www.ncbi.nlm.nih.gov/ pubmed/25716409

36. Gondim SMG, Pereira CR. Evidências de uma avaliação de medida de características pessoais de regulação de emoções. Psicol Reflex Crit [Internet]. 2015 Dec [cited 2016 Jan 11]; 28(4):659-67. Available from http:/ / www.scielo.br/scielo.php?script=sci arttext\&pid=S0102-79722015000400004\&lng=en\&n $\mathrm{rm}=$ iso 